\title{
An Overview of the Reformed Local Government in Macedonia
}

\author{
Mirjana Kraja Sejdini \\ Epoka University, Albania \\ E-mail: msejdini@epoka.edu.al
}

Received: April 29, 2016 Accepted: May 16, 2016

doi:10.5296/ber.v6i1.9350

URL: http://dx.doi.org/10.5296/ber.v6i1.9350

\begin{abstract}
Local government in Westerns Balkans has gone through various public administration reforms resulting from the era of New Public Management (NPM) developments that took place in developed countries. However, such reforms have not yet reached their goal of creating more autonomous (especially financially) local government units that would be efficient and effective enough to provide better services to citizens. Macedonia is perceived a country where fiscal decentralisation has not reached its expected outcome reflected mainly in low shares of finances compared to central government finances. This paper aims to elaborate on the reforms that have shaped the management of local government in Macedonia, as well as its financial position. This is an exploratory study of previous writings about decentralization and local government (mainly) in Macedonia. The paper starts with some theoretical background of NPM and decentralisation that have shaped the local government. Then it follows with a review of the public administration reforms, decentralisation process, and local government finances. The paper is expected to contribute modestly in understanding the nature of local government and its finances along the reforms channelled mainly through the decentralization process.
\end{abstract}

Keywords: Public administration reform, Decentralization, Local government finances, Macedonia

\section{Introduction}

Local government in Westerns Balkans has gone through various public administration reforms resulting from the era of New Public Management (NPM) developments that took place in developed countries. However, such reforms have not yet reached their goal of creating more autonomous (especially financially) local government units that would be efficient and effective enough to provide better services to citizens. Decentralization process was the main form of NPM application at local level. Therefore, it is an ongoing reform 
process for the local government (LG) of Macedonia. Its application has been mainly in form of legal reforms and decentralization programs starting even before the start (in 2005) of decentralization process itself in line with the European Charter of Local-Self-Government requirements. Eventhough there have been a number of studies that have elaborated on public administration (PA) reforms, on strategies of PA reforms, on the decentralized functions of local government, on fiscal decentralization, there has been no study that incorporates all of these in one to have a deeper understanding about the 'new' or 'reformed' local government in Macedonia.

Therefore, the aim of this paper is to provide a comprehensive elaboration on the reforms and decentralization, as well as the fiscal implication of LG in Macedonia. More specifically, the objectives of this paper are:

To elaborate on the reforms and related strategies that have shaped the local government provision with the decentralization as the main mode of offering services to citizens,

To analyze the financial position of the new decentralized local government

These objectives will be met by consulting papers. The data are taken from the Treasury Department within the Ministry of Finance of Macedonia. Comparative data with some EU countries are retrieved from EUROSTAT.

\section{The New Decentralized Local Government: Literature Review}

New Public Management shaped the public sector provision in 1990s. NPM was influenced was formed and influenced by both classical and neoclassical theoretical approaches. This influence resulted in managerial tools and techniques that became mostly used during the developments of NPM. Rhodes (1996) defines managerialism based on the NPM understanding and division of Hood (1991) as introduction of private sector management methods to public sector in form of hands-on professional management, value for money, and being close to the customers (Rhodes, 1996, p. 655). The managerial approach aiming at improving the public management and performance, as a result, came as a higher order function than administration (contributing to results and managerial responsibility) together with modern management theories and practices (contributing to flexible staffing and organization) (O'Flynn, 2007, p. 354). One of the most important development as far as management of public governance is concerned is the brave movement of public governance called reinventing government in the book by David Osborne and Ted Gaebler, Reinventing Government: How the Entrepreneurial Spirit is Transforming the Public Sector. The reinvention gospel called for importing private sector efficiency techniques to make government more results-oriented and less costly (Clark, 2013). It struck the nerve of not only the American government but also governments worldwide, while attempting to answer the main question: How to reinvent (American) bureaucracy (Osborne \& Plastrik, The Reinventor's Fieldbook: Tools for Transforming Your Government, 2000, p. 1)?

This movement was considered as a shift from the rigid, wasteful, centralized bureaucracies of the industrial era to the more flexible, entrepreneurial, decentralized government needed to succeed especially in a time where fiscal crisis was crippling American governments 
(Osborne D. T., 1993). Osborne (1993) recognized the need for creating entrepreneurial governments which would concentrate on earning money, rather than spending money (traditional governments) through the principles of (1) catalytic government; (2) community-owned government; (3) competitive government; (4) mission-driven government; (5) results-oriented; (6) customer-driven; (7) decentralized; and, (8) market-driven government.

Unlike any other movement in PA, the fundamentals of reinventing government were elaborated and developed further in specific and guiding strategies of applying these principles in the management of public sector worldwide in the book Banishing Bureaucracy: The Five Strategies for Reinventing the Government in 1997 by David Osborne and Peter Plastrik. These strategies ultimately were designed to create such organizations that habitually would innovate without pushing from outside but rather with a built-in drive to improve or "self-renewing systems" (Osborne \& Plastrik, 1997).

NPM can be characterized as a shift in the mentality and concerns about performance measurements, including efficiency, eventhough, it did not translate more in an administrative doctrine with specific implementations in the public sector. However, it did provide some major tenets and principles that could be used in various contexts (countries), various levels of government, and various non-for-profit organizations. Most importantly, NPM contributed to the notion that public organizations do have space for applying business-like techniques in order to increase their performance by being more effective and yet efficient.

The European local government was influenced too by these changes and its reform was characterized by a reform and strategy logic to enhance LG leadership and later into another reform geared to NPM and EU market liberalization aiming to re-organize local government provision through “outsourcing' or 'privatization' (Wollman, 2012). The resulting modes of this new public management philosophy, was characterized mainly through decentralized local government provision. Developing countries and transitional economies (including Macedonia) have reformed their local government through a process of decentralization. This process has been driven and funded by international institutions such as World Bank, IMF, etc. Its main aim was liberalizing the market and contributing to further country democratization, more efficient and effective public administration and good governance.

Decentralization theory foundation is laid by Stigler's jurisdiction principles in 1957: better government are those closest to people and people should have their voting right for their preferred public services. This theory was advanced by various scholars defining local government provision as a legitimate right of those jurisdictions having control over the minimum geographic area that would internalize benefits and costs of such provision (Oates, 1972)". This legitimacy is explained by the fact that local government understands better citizens' preferences; acts faster encouraging so greater fiscal responsibility and efficiency; contributes to removal of bureaucratic layers in PA; and have greater opportunity for interjurisdictional competition and innovation (Shah, 2006).

Decentralization has had its pro and against arguments. Pertaining to its results in transitional economies, some authors argue that decentralization did not produce the same expected 
results as in industrialized or developed countries because it did not meet three basic criteria of local accountability: voice, rules of implementation, and oversight arrangements (White, 2011). Lack of accountability does not allow for better matching between local provision and citizens expectations.

Fiscal decentralization has been focused more on structures and processes compared to outputs and outcomes, often leading into 'centralized' systems or central micromanaging (Shah, 2006). This has led into decentralized competencies on technical and administrative basis, rather on citizen orientation, local accountability or lower transaction costs for citizens. Answers to these issues are perceived into citizen-oriented local governance on the principles of responsive, responsible and accountable governance (Shah, 2006).

The developed countries models have exercised these principles in different forms. The US model treats local government as State responsibility. Therefore, LG units exercise their powers under state legislation with most of the states granting autonomy in specific functions. Nordic countries preserve wider regulatory and functions (more than 30 percent of GDP) due to citizens' satisfaction. They prefer smaller municipalities, but with self-financing reliance (65-75\% of total revenues). Swiss canton system enjoys today not only fiscal autonomy but also autonomy on immigration, citizenship and economic relations. Cantons enjoy a great autonomy politically, too. French model stresses local service delivery (10 percent of GDP) at local level with policy making functions at central level. Revenue sharing is the main source of LG financing. British system of LG gives a great deal to the officers and sectoral offices assigned centrally. Local government is responsible in property-related services, while people related services remain under central government responsibility. Similarly, Australian constitution does not recognize the local government. Its functioning (minimum services amounting into 6 percent of public sector expenditure) depend on states.

\section{Decentralization and Local Government in RM}

Decentralization process is perceived as an ongoing reform process for the local government (LG) of Macedonia. This process was mainly in for of legal reforms and decentralization programmes applied even before the start of decentralization process itself (in 2005) in line with the European Charter of Local-Self-Government requirements. Furthermore, the chapter offers a definition of budget and budget process and reviews it in the context of LG of Macedonia. At the end, there are some concluding remarks pertaining to the nature of reforms and decentralization in the country which contribute in understanding the basis on which an assessment for the LGU performance is carried.

Decentralization has shaped the local government in RM as an outcome of the PA reforms and local government (fiscal) reforms that have been carrying in the country. In this section, there is an overview of these reforms, decentralization phased approach applied in the country and reforms specifically to the local government sector in RM.

Having a deeper understanding about local government developments and their nature requires some background information for Macedonia. The country, formally known as FYROM, had to go through a major shift, from a republic of ex-Yugoslavia with enriched 
decentralization experience, to a country centralizing itself while striving towards an independent market economy. Political events culminating with the 2001 internal ethnic conflict between the two largest ethnic groups, Macedonians and Albanians, shaped the landmark of decentralization or delegating power to other non-Macedonian ethnic groups. OHA is considered one of the pushing factors to the decentralization because it was seen as the best way for shared power by empowering local communities of various ethnic backgrounds. For Albanians this meant shared political power and cultural acceptance in return to acknowledging the country's institutions. Yet, there are some important achievements of the country, which could have been utilised and invested more on. Country remains with the challenges of further Euro-Atlantic integration processes by de-politicizing institutions and establishing rule of law for all.

Power sharing among various ethnic groups in the society of Macedonia started after the 2001 conflict and with OFA agreement. There was a municipality restructuring in August 2004, which was supposed to serve as a mechanism that would allow Albanians and other ethnic groups to have more decentralized power in exercising their duties and rights. In 2013, there was a minor restructuring of the municipalities. Now, the Local Government Units (LGUs) that represent the administrative units of local government consist of 84 first-order administrative units or municipalities, out of which 10 municipalities make up the City of Skopje (Greater Skopje) municipality which has a distinct status.

\subsection{Reasons for Decentralization in Macedonia}

To summarize all of the developments vis-a-via decentralization, there were five profound reasons of decentralization the country regarded as essential, which were given in 2000 before the 2001 internal conflict - by (Robert W. Rafuse, 2000), in addition to the after-conflict need for power-sharing among all ethnic groups in Macedonia:

1. Earlier than the real time of decentralization (early 2000s), Macedonia ratified the European Charter of Local Self-Government (in 1997), thereby agreeing on the central principle that decentralization is an essential attribute of the democracy of local government. Very soon Macedonia was criticized for its slow process of decentralization and then conditioned to take local government genuine reforms to be a serious candidate for EU membership.

2. The local government accountability towards its citizens that require qualitative public services will not take place if local government officials or providers of such services will logically use the excuse that central government does not provide money for community.

3. Substantial fiscal decentralization is perceived as the mode of providing more efficient local governments services, as the taxpayers are closer to their service providers. This is in line with theories of public sector efficiency as well as the practices of most of the countries which recognize that local government officials are more careful in spending the taxes they receive by their voters as compared to transfers from central government.

4. Managerially speaking, local government are at a much favorite position I offering public services according to the local conditions as well as preferences compared to the higher levels 
(ministries) bureaucrats.

5. The OFA agreement which accelerated the decentralization process itself as a need to share power at community level, allowing respective communities to provide some basic public services by their own community.

\subsection{PAR Reforms and Strategies}

It would be limited without understanding first the general scope of public administration reforms (PAR).

Considering the time of starting the decentralisation efforts in Macedonia, as well as the world and European context and influence of new public management approach (especially by the European Charter of LG), one may say that the local government reform in Macedonia has been pushed by two main factors: the developments and the resulting reforms of New Public Management at world level as well as European countries; and, the country's domestic turmoil (in 2001) which ended with the OFA Agreement that would guarantee shared governance (especially local governance) among Albanian ethnic group as well. Therefore, decentralization was seen as the best outcome to the local government reform incorporating market-related approaches and mechanism and more inclusion in form of shared authority at local government to all ethnic groups for the purpose of better local government services.

Development of Public Administration Strategies (PAR) has been an ongoing challenge and yet priority to the country since its independence reflected into the first strategy on PAR in 1999 and the current Strategy on PAR 2010-2015.

After its independence, Macedonia had to go through a general reform of its Public Administration with the aim of creating a public administration that could adjust the country's shift towards an open market economy and a pluralist democracy. According to (Markic, n.d.), there was not much done - besides the introduction of state audit, the Ombudsman, public procurement regulation, and Organic Law on Budgets - until the adoption of the Strategy on PAR in May 1999, considered as crucial to the further democratic and economic developments of the country, as well as the economic integration with EU. In addition, the 1999 PAR Strategy is considered as the key document on which the whole PAR strategy was based (Markic, n.d.) and it served as a blueprint for the legal documents adopted later (Analytica, 2007).

The PAR strategy was complete enough to provide provisions on the strategy implementation itself. It elaborated in the establishment of inter-ministerial Commission for PAR with its base in the Ministry of Justice, which is replaced now with the Unit of Public Administration Reforms with its base in government's General Secretariat. The strategy's aim was to foster the public and democratic values of rule of law, transparency, competency, stability, accountability, responsibility, equal treatment, efficiency and ethics (Analytica, 2007). These values would be enhanced by targeting the areas (that were stressed in the PAR strategy) of state administration system, the overall PA system, the local self-government system, the redefinition of the role of the state, the realization and protection of citizens' rights, the restructuring of public finances, the development of information systems, etc (Azizi, 2011). 


\section{$\triangle 1$ Macrothink}

Business and Economic Research

ISSN 2162-4860

2016, Vol. 6, No. 1

The PA reforms were accelerated further with the OFA signing and the Stabilization and Association Agreement (SAA) with EU in April, 2009.

PAR still remains one of the main priorities of government which is emphasized in the new Strategy on PAR 2010-2015 (HD-IPS, 2010). The strategy recognizes the need for further reform and most importantly, modernization of PA system with a selective approach (rather than a radical one as in its predecessor) by selecting specific determined actions and changes within the actual context of country's development and needs (HD-IPS, 2010). Within this context, the government considers PA reforms and EU integration process as an interrelated process. The implications to the service delivery level means that such delivery should be more economic, effective and efficient up to the international and European standards as well. Another very important aspect pertaining to the approach of achieving these results is that the successful experiences of other countries cannot provide a clear roadmap. However, one should bear in mind that there a set of standards and principles in the field of PA which took the form of concepts out of 'benchmarking' and 'best practices' and the so called 'European Administrative Space". Countries of Western Balkans and Macedonia can generate similar solutions but with an adjusting approach to the own circumstances.

The new strategy recognizes the following objectives within PAR: improved quality of administrative services by improving and rationalizing administrative procedures in a simplified and interconnected approach through IT solutions or e-government; improved public services by strengthening HRM (especially training); improved strategic management of General Secretariat as Center of government; raised efficiency and effectiveness of the public finance systems by improving budgetary process, financial control, further development of program-based budgeting, and fostering more transparent public procurement system; and, improved transparency of PA by better public information access (HD-IPS, 2010). Therefore, the issues of improved quality, improved efficiency and effectiveness remain as the main objectives in modernizing the PA.

Pertaining to the achievements of PAR, evaluation studies (Azizi, 2011) (Analytica, 2007) based on EU progress reports and the General Secretariat evaluations, and the new strategy (HD-IPS, 2010) itself show that the initial attempts and the first PAR strategy contributed more on providing the necessary legal framework of transforming the PAR principles into legal norms. The implementation part of the 1999 strategy contributed to the institutional building and creating accountable institutions for implementing PAR strategy itself. However, the fact that PAR remains still as a main government priority shows that the implementation of the legal framework is the most crucial and yet less successful part of PAR efforts. Concerning the local government performance, issues of financial controls and audit (internal and external), continuation of decentralization process, increased transparency, and de-politicization of public administration question the adequate performance and efficiency of local government.

\subsection{Legal Reforms and Decentralization Programs}

The charter of Local Self-Government as a modern, pragmatic, flexible legal instrument gave more impetus in reforming the local government with the aim of protecting the rights of local 
authorities as closest to the citizens and enabling them effective and wide participation in solving local problems (MOF, 2009). The charter is one of the important pillars of democracy and the European integration and a first multilateral legal instrument that guarantees a high degree of local autonomy for the country. Later on, with the candidate EU status (2005), the reform was accelerated by the need to absorb the EU pre-accession assistance.

At micro level, decentralisation was accepted as a market related approach that could allow public service provision closer to its citizens and within their expectations. Within these priorities, the PAR strategies included the local government in terms of providing the legal framework for self-financing, territorial management, and specific local services management within the agreed process of decentralisation. It is important to note that the need for PAR strategies was very ambitious for the country, which had to deal more with macroeconomic stability at the beginning years of its independence. The resulting mechanism of decentralisation was very ambitious to design (especially through the establishment of the necessary legal reforms) nevertheless to implement in a status of local government (according to Nikolov, 2006) left without competencies and inefficient system of financing (1991-1995).

The LG reform as a way of giving governance and authority back commences formally by the government of Macedonia in 1999 with the enactment of the Strategy for the Reform of the System of Local Self-Government in addition to the establishment of the Ministry of Local Self-Government. The strategy anticipated the reduction of the LGUs in number, increased competencies of local government, as well as increased financial independence. The resulting push for further decentralization came out of OFA in form of Constitutional changes guaranteeing the right to local self-government and generating laws on local self-government (Markic, n.d.). In other words, the constitutional changes gained momentum to the implementation of the strategy and acceleration of the decentralization process itself. One positive indicator for such acceleration was the forming of a Coordinative Body of State Secretaries for planning, monitoring, managing and coordinating of the reform.

However, there are critics (Nikolov, 2006) that the decentralisation process was a politically-driven process rather than one that was supposed to be driven by fiscal and competency decentralization to form more efficient public providers (local governments). In addition, the reversed approach was characterised with delegated revenues prior to the delegated expenditure assignments. Additionally, certain delegated duties had to come from line ministries which often has served as barriers to the process of decentralization, rather than showing willingness of delegating their authority, which is shown also in decentralization assessment studies (OSCE, 2011), where municipalities indicate the lack of communication with such institutions as one of their biggest cooperation challenge.

One of the milestone developments in the process was the adoption of the Law on Local Self-Government in January 2002, which specifically defined the organic structure and competencies, as well as regulating the operations of LGUs. The following and supporting laws were: The Law on Financing of the Units in Local Self-Government (referred as Law on Financing) and the City of Skopje adopted in July 2004 (Official Gazette of RM no. 61/2004 and 96/2004); and, the Law on Territorial Organisation adopted in August 2004 (Official 
Gazette of RM no. 55/2004). Both of these laws regulated the nature of service that could be provided by local self-government units and the new territorial division of 84 LGUs and the City of Skopje.

The above legal consolidation gave the push for starting a substation process of decentralization in Macedonia, which is known to have started in 1 July 2005 and in form of two transfers: the administrative (of human resources, equipment, and property) and financial transfer (OSCE, 2011). For each of the delegated and other local services there were laws adopted. All of these laws offered an effective legal framework for regulating the decentralization process. However, the new territorial division was criticised for trading principle efficiency with the principles of democracy, because, suddenly there were new formations and changed boundaries of municipalities questioned in their sustainability due to lacked capacity of generating own revenues.

PAR strategies were associated with a number of operational programmes to foster the implementation of the decentralization process and LG management. These programs were:

1. Operational Programme for Decentralization of Powers 2003-2004 - mainly contributed to the institutional infrastructure and support to the decentralization by establishing the Inter-Ministerial Decentralization Work Group, the Coordinative Body of State Secretaries, by signing a memorandum of understanding with the Association of the Units of Local Self-Government (ZELS) and Civil Service Agency for providing necessary training.

2. Programme for Implementation of the Process of Decentralization 2004-2007

3. Detailed Plan for Transfer of Competencies and Resources 2005

4. Programme for Implementation of the Process of Decentralization 2008-2010

5. Programme for the Implementation of the Process of Decentralization 2012-2014

All of these laws and programmes aimed at supporting the decentralization process and specifically to:

$>$ continue effectively and efficiently the ongoing process of decentralization;

$>$ balance the movement of LGUs to higher phases of decentralization, especially to support the movement of all municipalities from the first phase;

$>$ strengthen the local government capacity of debt management;

$>$ strengthen the local government capacity of general management;

$>$ increase accountability and transparency;

$>$ increase citizen inclusion in the process of decision making;

$>$ foster further the existing partnership, especially inter-municipal cooperation; and,

$>$ ensure balanced regional development and reduce municipal disparities.

Considering the number of laws adopted (before and after the decentralisation commencement in 2005) as well as the coherent operational and implementation programmes to the process of decentralisation, one can argue that the country went through a tremendous progress from the legal and infrastructural support. 


\subsection{Decentralization and its Phases}

With the commencement of decentralization process in 2005, the local government was not ready to deliver a broad range of public services. Therefore, The Law on Financing regulated the decentralization process in a number of decentralization phases, which was considered to be optimal in addressing risks of decentralization to the efficiency of public spending and fiscal sustainability. While LGUs were supposed to roll over to the next phase, the implications were in form of additional decentralized services together with financial resources.

The Article 22 of the Law on Local Self-government regulated the transfer of the following public services through the staged decentralized process from the central level to the local one:

Urban and rural planning;

$>$ Protection of the environment;

$>$ Local economic development;

$>$ Communal services - water supply, sewerage, public hygiene, waste management, public transportation, local roads construction and maintenance;

$>$ Culture;

$>$ Sports and recreation;

$>$ Social welfare and child protection

$>$ Primary and secondary education

$>$ Healthcare

$>$ Protection and rescuing activities of citizens and goods

$>$ Fire-fighting

$>$ Supervision and monitoring over the performance of LGUs undertaken competencies Eventhough, the law regulated a two-phased approach to decentralization, there were de facto three phases: the zero or preparatory phase, the first, and the second phase.

Zero Phase or preparatory phase (2005-2007) represents an integrated approach including central government and the local unit for restructuring and consolidating the minimum capacity for financial management. From the municipal financing point of view, this phase was supposed to strengthen incentives for revenue collection by the municipalities; increase municipal revenue potential; and improve municipal revenue raising capacities. These preconditions were to be established mainly through abolishing the grant from surplus revenue and through allowing municipalities to collect their own revenue from their current tax bases. A series of institutional arrangements was supposed to attach to the initial phase, such as: enforcement of budget preparation procedures and improvement of budget planning by abolishing the fragmentation of municipal budgets; strengthening of municipal budget management by improving the accounting system; strengthening of internal expenditure control mechanisms; and, enhancing the reporting of municipal budget execution to the central government.

First Phase allowed for local government to accept assets and related maintenance costs (buildings, school heating, supporting staff, etc). At this stage of decentralization, municipalities were assumed to have created their own revenue generation and they would 
have additional shared revenues (based on a distribution formula) of personal income tax and value added tax (VAT). Earmarked grants were covering the maintenance costs of decentralized institutions. There were higher expectations pertaining to the internal capacity building and financial management fostering audit - by appointing municipal internal auditors, initiating performance audits, and developing and adopting formal procedures to initiate follow-up on State Audit Office reports.

Second Phase represents the most advanced stage of decentralization, where it was assumed that municipalities would meet specific conditions of the first phase. Municipalities were supposed to show positive financial results for at least 24 months. The decision making power was expected to be increased from the maintenance of institutions/facilities at local level, up to the level of managing human and financial resources needed for their operations. The focus was more on developing HR capacities and improved budget systems. In addition, for transfers of specific programs, LGUs could use their own revenues as well as specific grants.

\subsection{Local Government Fiscal Reform}

Aiming at creating a consolidated local government, most important modifications (July 2005) to the existing financial system included:

article abolishing on Law on Budget pertaining to the cap removal on local own revenues to allow for increased tax base and revenue collection

$>$ abolishing of the Law on Limitation of Own Source Revenues allowing LGUs for stronger financial tax base

Then, the Law on Financing regulated the reform in form of:

$>$ transferred full responsibility in administering and collecting property transfer tax, property, tax, gift, and inheritance tax;

$>$ the right for 3 percent share of personal income tax that central government collects out of jurisdictions in one's municipality and whole (100\%) of tax on independent artisans;

$>$ the right for 3 percent share out of VAT collected at national level in form of earmarked grants with the condition that at least 50 percent of the total VAT to be distributed on per capita basis except for the city of Skopje and its LGUs;

$>$ The equalisation scheme or formula is determined by the Ministry of Finance in consultations Committee for Monitoring and Development of Local Government Finance System that has members from national as well as local government (through ZELS).

$>$ The law regulated also the two-phased decentralisation process explained in the previous section.

Another fiscal reform pertaining to the revenue generation of LGUs is a significant amendment of Local Government Self-Financing (in 2009), where Government approved to have a gradual VAT increase from 3-4.5\% to the revenues of LGUs (OSCE, 2011, p. 21). Currently, the LGUs are channelling their voice through ZELS and their target is to increase such share up to $6 \%$. 


\subsection{Local Government Finances}

The resulting reforms as stipulated mainly in the law on Financing Local Self-Government Units have shaped the profile of local government system and its operations to generate their own revenues, accept transfers from the central budget, and borrow domestically and internationally. From the expenditure point of view, LGUs are supposed to reflect all of their expenditure decisions in form the operational budget which requires the LGUs to adopt quarterly and yearly.

Own Revenues. This category represents those revenues under full responsibility of the municipality, which consist of: Local taxes - property tax, the inheritance tax, and gist tax; local fees - communal fees, administrative fees, and other local fees; local refunds - funds for construction land arrangement, utility refunds, refunds pertaining to spatial and urban development plans, and other refunds; and, revenues from ownership - property sales revenues, rent revenues, and interest rate revenues, and other revenues from donations, fines and self-contributions.

Shared Revenues. These revenues are filled with 100\% of the PIT (Personal Income Tax) coming from local residents involved in craftsmanship (jewellers, silversmiths, tailors, etc) and $3 \%$ of revenues generated from the PIT of municipalities' residents in form of salaries where the employer is responsible for paying the PIT on behalf of the employee. The transfer goes through the treasury system automatically, leaving no room for discretionary decisions by the central government. PIT revenues may be used at LGUs' discretion.

Intergovernmental Transfers. These transfers include those coming from the central budget as well as the funds operational in RM, such as Road Fund, Water Fund, and Fund for Balanced Regions. These transfers are classified in the municipal finances as:

$>$ Earmarked Grants - grants for financing a destined activity only, without municipality decision upon their use. Earmarked grants include mainly operation or maintenance costs resulting from education, social care, and firefighting. Wages and salaries in all of these sectors are not included.

$>$ Block Grants - grants used to finance the major municipal services such as education, culture, etc. With the delegated competencies in pre-tertiary education a large amount of the budget and earmarked grants consist of the salaries of teachers. In other words, block grants consist of earmarked grants and wages and salaries paid to employees employed in the local government service areas for which these grants are assigned.

$>$ Revenues from VAT (Value Added Tax) - revenues that are allocated to the LGUs in form of monthly transfers from the central budget. They do not belong to the earmarked grants. Therefore, municipality decides on their use depending on the municipal priorities.

$>$ Capital Grants - grants to be used to finance capital projects. Government adopts yearly plans for such projects and assigns grants accordingly.

$>$ Grants for a delegated competency - grants to be used to finance a recent delegated competency from the central government, such as elderly care. The grants are determined by the contract signed between the Mayor and the ministry the competency is devolved from. 
This classification together with the criteria announcement given by line ministries and Funds allows the municipal finance decision makers to anticipate the revenues of their municipality. The VAT distribution is a very important channel of revenue generation. Municipalities are entitled to $3 \%$ of the VAT collected in the previous fiscal year, allocated to them on the basis of criteria determined in the Decree on the Methodology of Allocation of Property Tax Revenues, adopted by the Government. The distribution formula seems often very complex and not transparent enough to understand, even from the municipal and ZELS officials themselves. The variables involved consist of population, territory, and number of settlements. This grant is established as an equalization scheme to narrow the revenue disparities among rural and urban LGUs.

Revenues from Borrowing. Along the decentralized fiscal competencies, LGUs have the right to borrow under the law and regulations of the country for capital and operating purposes. The rules define the limitations of the borrowing as well (Nikolov, 2006) pertaining to total amount borrowing capacity, long-term dues, and other borrowing terms.

Equalization Scheme. The significant differences in the local tax bases could potentially result in inherently unfair and inefficient fiscal decentralization. A community with high tax bases can finance a given level of services with lower tax rates than a community with low tax bases. This is widely regarded as an unfair situation. The distribution mechanism of the equalization funds was just as unclear as the process of its collection. The Ministry claims to use criteria such as budget deficiency (difference between the budget size predetermined externally by the same Ministry in advance) and budget performance, which would make the grant a "gap-filling" transfer, albeit a partial one. But other criteria might also have been used, including political considerations.

\subsection{Local Government Budgeting}

The local government budgeting process is guided by the Law on Financing, requiring LGUs to prepare separate capital budget and operational budget. However, most of the LGUs report more regularly, including even quarterly reports, on operational budgets. LGUs budgeting still is far from performance budgeting, eventhough there have been some donor-based programs (Nikolov, 2006).

The Municipality Budget is prepared on the guidance (draft) provided by the Ministry of Finance and the Law on Budgets. The next year's budget preparation should start latest by September $30^{\text {th }}$ each year. The Municipality Council approves the yearly operational budget latest by 31 December. The Mayor makes the budget proposal. The Municipality Council is obliged to pass a decision on temporary financing, if it fails to approve the budget proposal. The approved budget must be balanced (no room for deficit) and it should be sent by the LGU to the MOF within 15 days after its approval, to be further aligned by this ministry with the central budget (expenditures). After the approval, the LGU prepares a decision to implement the approved budget, where LGUs are obliged to respect the spending specifications.

Before making the budget proposal, MOF sends a budget circular to all of the LGUs to: 
inform them about economic indicators; give guidance for budget preparation, inform about the assigned transfers from the national budget, and inform LGUs about the possible sources of income. The Mayor should inform all of the beneficiaries, including citizens, and ask them to submit their financial plans. After this submission, the Mayor prepares the budget proposal to the Municipal Council for discussion and approval. In case where there some unanticipated revenues or expenditure, the Mayor may ask for budget rebalancing (amendments) to the Municipal Council's approval. For example, in 2013, some LGUs did not anticipate the increased revenues out of the delegated competency of construction permit; therefore, there was a need for budget rebalancing. In addition to budgeting, LGUs are obliged to complete the financial management through: accounting, treasury management, reporting, and auditing.

Macedonia still remain a country where stakeholder (especially citizen) involvement in budgetary decisions remain very low. Citizens do not have access even to the approved budget of their municipality, not to mention the fact that they rarely have a grip on the document of the budget proposal sent by the Mayor. Still, LGUs in Macedonia do not publish electronically in the website the approved budget. At least, such important document could serve as a performance measure for citizens and other stakeholders to access and monitor municipal activities.

\section{Analyzing Local Government Finances in RM}

This section will provide some descriptive analysis of the local government budgetary data after the decentralization limited to the availability of the data. First, there will be a comparison approach with some EU countries to judge the level of decentralisation in Macedonia. Then the analysis will be focused more on the municipal budgets and data for all LGUs in the country. Such analysis helps in having a deeper understanding about the financial status and certain trends of LGUs. It is important to note that this section provides the main aspect of local government performance. However, the overview would be complete if there were data and financial reports such as balance sheets in addition to the operational budget of LGUs.

\subsection{Level of Decentralization Compared to some EU Countries}

To show the fiscal decentralisation level, the general, central, and local government revenues and expenditure as percentage of GDP of Macedonia are compared with the European Countries (28 countries). They are presented in Table 1 and 2.

General Government Revenue (GGR) of EU varies from 43.5 to 45.3 percent of GDP, while it varies from 37.5-38.5 for Macedonia (see Table 1.) GGR of EU is higher by an average of about 6 percent compared to that of RM, while General Government Expenditure (GGE) of EU is higher by an average of about 7 percent for the period of 2010-2013. As expected, there is a greater difference regarding the central and local government expenditures and revenues. CGR of RM is rather higher compared to EU by around 12 percent. There is a similar difference pertaining to CGE. Regarding the local government revenues, LGR of EU varies from 11.6 to 11.3 percent to GDP, while LGR of MK varies from 2.0 to 2.7 percent of its GDP. On average, there is a great difference of about 8.7 percent. Similar picture is portrayed regarding the local government expenditure. The aim of Macedonia's local government 
association ZELS, which channels the voice of the LGUs through its mayors, is to have reached by this time a level of $4 \%$ to the GDP.

Table 1. Government Revenues of EU and Macedonia (\% of GDP)

\begin{tabular}{|l|l|c|c|c|c|c|}
\hline & Indicators & $\mathbf{2 0 0 9}$ & $\mathbf{2 0 1 0}$ & $\mathbf{2 0 1 1}$ & $\mathbf{2 0 1 2}$ & $\mathbf{2 0 1 3}$ \\
\hline \multirow{4}{*}{$\begin{array}{l}\text { European } \\
\text { Countries }\end{array}$} & General Government (GGR) & 43.5 & 44 & 44.6 & 45.3 \\
\cline { 2 - 7 } & Central Government (CGR) & & 23.1 & 23.2 & 23.8 & 24 \\
\cline { 2 - 7 } & Local Government (LGR) & & 11.6 & 11.4 & 11.5 & 11.3 \\
\hline \multirow{4}{*}{ Macedonia } & General Government (GGR) & 37.5 & 37.8 & 38.3 & 39.2 & 38.5 \\
\cline { 2 - 7 } & Central Government (CGR) & 35.4 & 35.2 & 35.7 & 36.1 & 35.8 \\
\cline { 2 - 8 } & Local Government (LGR) & 2.0 & 2.5 & 2.6 & 3.0 & 2.7 \\
\hline
\end{tabular}

Source: Author's calculations from EUROSTAT and NBRM data.

Table 2. Government Expenditure of EU and Macedonia (\% of GDP)

\begin{tabular}{|c|l|c|c|c|c|c|}
\hline & Indicator & $\mathbf{2 0 0 9}$ & $\mathbf{2 0 1 0}$ & $\mathbf{2 0 1 1}$ & $\mathbf{2 0 1 2}$ & $\mathbf{2 0 1 3}$ \\
\hline \multirow{4}{*}{$\begin{array}{c}\text { European } \\
\text { Countries }\end{array}$} & General Government (GGE) & & 50 & 48.5 & 48.9 & 48.6 \\
\cline { 2 - 7 } & Central Government (CGE) & & 28.6 & 27 & 27.7 & 26.9 \\
\cline { 2 - 7 } & Local Government (LGE) & & 11.9 & 11.5 & 11.5 & 11.4 \\
\hline \multirow{4}{*}{ Macedonia } & General Government (GGE) & 40.5 & 40.6 & 41.4 & 43.9 & 43.6 \\
\cline { 2 - 7 } & Central Government (CGE) & 38.4 & 38.0 & 38.7 & 40.8 & 40.7 \\
\cline { 2 - 7 } & Local Government (LGE) & 2.1 & 2.5 & 2.7 & 3.1 & 2.9 \\
\hline
\end{tabular}

Source: Author's calculations from EUROSTAT and NBRM data.

\subsection{Local Government Revenues and Expenditure}

This part offers an overview of the budgetary experience of LGUs in Macedonia especially starting at the year of decentralization (2005) until the recent available data. The overview is in form of a time trend of revenues consisting of capital, non-tax, tax revenues, as well as transfers and grants from the central government to the LGUs. Additionally, there are details about the basic categories of budgetary expenditure of LGUs. The trend of either revenues or expenditure over the time in consideration will be in form of detailed structure of both categories as they are structured in the final accounts of the local government. The OSCE reports on decentralization (OSCE, 2011) are combined with the authors calculations based on financial accounts of local budgets.

Tables 3 and 4 provide an overall trend of the total revenues and expenditure and their respective items. Total revenues during 2005-2011 has increased in monetary value from $€ 87.8$ million in 2005 to $€ 441.5$ million in 2011, which show a total increase of almost 5 times over 6 years in consideration (see Table 2-9). As seen in Chart 1, the non-tax revenues and capital revenues have remained steady with a slight increase, while the tax revenues have increased fairly in yearly terms, but doubled over 6 years from $€ 51.5$ million in 2005 to $€ 108.6$ in 2011 .

There is a different picture for transfers and grants (as expected though), where there has been a substantial increase (from $€ 33.1$ in 2005 to $€ 257.7$ million) over the six years due to the 


\section{MInstitute ${ }^{\text {Mank }}$}

Business and Economic Research

ISSN 2162-4860

2016, Vol. 6, No. 1

increased competencies of local government, mainly due to the wages and salaries in primary and secondary education. As seen in Chart 1, there is a sudden jump in 2007, because that is when many LGUs managed to move to the second phase of decentralization and the wages and salaries in education went through their budget in form of transfers and grants. This is shown in the trends of wages and salaries (see Chart 2) where there is a similar trend.

In line to these changes, it is expected that the participation of each revenue sources has changed over the years. If tax revenues represented the main participation to the LG total revenues in 2005 (by 58.7\%), this leading place was switched to transfers and grants in 2007 and it represented 63 percent of total revenues in 2011. All of this analysis leads to a very important conclusion that LGUs still have little financial resources to manage, because transfers are mainly conditional ones. However, this should serve as a need for LGU mayors and administration to increase their potential of revenue generation and make sound financial management decisions.

Overall expenditures follow similar trends to revenues (see Table 2 and Chart 2). With the increased decentralization, there is a similar change in 2007. As it was mentioned above, the wages and salaries had the largest increasing trend (from $€ 1.1$ million in 2005 to 202.9 million in 2011) and a significant jump in 2007. There has been a significant increase of $€ 25.3$ million in 2005 to $€ 99.7$ million in 2011 in goods and services used by the municipal administration, which would have been great if the same trend was followed by own revenues of municipalities. This would show betterment in regards to municipal services, because it shows own revenue generation capacity of local government.

Table 3. Local Government Revenues Structure 2005-2011 (in million Euros and \%)

\begin{tabular}{|c|c|c|c|c|c|c|c|c|c|c|c|c|c|c|}
\hline LG Revenues & 2005 & 2005 & 2006 & 2006 & 2007 & 2007 & 2008 & 2008 & 2009 & 2009 & 2010 & 2010 & 2011 & 2011 \\
\hline Capital Revenue & 0.07 & $0.1 \%$ & 1.38 & $1 \%$ & 1.96 & $1 \%$ & 2.85 & $1 \%$ & 11.32 & $3 \%$ & 25.53 & $7 \%$ & 23.43 & $6 \%$ \\
\hline Non-Tax Revenue & 3.06 & $3.5 \%$ & 18.15 & $14 \%$ & 21.50 & $12 \%$ & 19.52 & $6 \%$ & 19.39 & $5 \%$ & 20.50 & $5 \%$ & 21.80 & $5 \%$ \\
\hline Tax Revenue & 51.54 & $58.7 \%$ & 56.30 & $43 \%$ & 68.78 & $38 \%$ & 98.47 & $29 \%$ & 79.91 & $21 \%$ & 96.23 & $25 \%$ & 108.57 & $26 \%$ \\
\hline Transfers and Grants & 33.14 & $37.7 \%$ & 54.97 & $42 \%$ & 89.80 & $49 \%$ & 220.74 & $65 \%$ & 265.03 & $71 \%$ & 244.37 & $63 \%$ & 257.66 & $63 \%$ \\
\hline Total & 87.81 & $100.0 \%$ & 130.81 & $100 \%$ & 182.05 & $100 \%$ & 341.57 & $100 \%$ & 375.64 & $100 \%$ & 386.63 & $100 \%$ & 411.46 & $100 \%$ \\
\hline
\end{tabular}

Source: OSCE database of annual accounts of the local self-government units for the years 2005-2011(updated from the author)

Table 4. Local Government Expenditure Structure 2005-2011 (in million Euros and \%)

\begin{tabular}{|l|l|r|r|r|r|r|r|r|r|r|r|r|r|r|r|}
\hline Code & Category & $\mathbf{2 0 0 5}$ & $\mathbf{2 0 0 5}$ & $\mathbf{2 0 0 6}$ & $\mathbf{2 0 0 6}$ & $\mathbf{2 0 0 7}$ & $\mathbf{2 0 0 7}$ & $\mathbf{2 0 0 8}$ & $\mathbf{2 0 0 8}$ & $\mathbf{2 0 0 9}$ & $\mathbf{2 0 0 9}$ & $\mathbf{2 0 1 0}$ & $\mathbf{2 0 1 0}$ & $\mathbf{2 0 1 1}$ & $\mathbf{2 0 1 1}$ \\
\hline 40 & Wages and Salaries & 1.1 & $2 \%$ & 1.9 & $2 \%$ & 43.3 & $27 \%$ & 144.7 & $48 \%$ & 170.1 & $50 \%$ & 202.9 & $48 \%$ & 202.9 & $48 \%$ \\
\hline 41 & Reserves & 0.4 & $1 \%$ & 0.4 & $0 \%$ & 0.3 & $0 \%$ & 1.5 & $0 \%$ & 1.5 & $0 \%$ & 1.3 & $0 \%$ & 1.3 & $0 \%$ \\
\hline 42 & Goods and Services & 25.3 & $36 \%$ & 56.0 & $54 \%$ & 64.2 & $40 \%$ & 79.2 & $26 \%$ & 90.7 & $27 \%$ & 99.7 & $24 \%$ & 99.7 & $24 \%$ \\
\hline 44 & Current Transfers & 0.3 & $0 \%$ & 0.0 & $0 \%$ & 0.0 & $0 \%$ & 0.0 & $0 \%$ & 0.0 & $0 \%$ & 0.0 & $0 \%$ & 0.0 & $0 \%$ \\
\hline 45 & Interest Payments & 0.0 & $0 \%$ & 0.0 & $0 \%$ & 0.0 & $0 \%$ & 0.0 & $0 \%$ & 0.0 & $0 \%$ & 0.1 & $0 \%$ & 0.1 & $0 \%$ \\
\hline 46 & Subsidies and Transfers & 3.6 & $5 \%$ & 3.7 & $4 \%$ & 5.9 & $4 \%$ & 11.3 & $4 \%$ & 10.7 & $3 \%$ & 14.6 & $3 \%$ & 14.6 & $3 \%$ \\
\hline 47 & Social Benefits & 0.1 & $0 \%$ & 0.2 & $0 \%$ & 0.2 & $0 \%$ & 0.2 & $0 \%$ & 0.3 & $0 \%$ & 4.4 & $1 \%$ & 4.4 & $1 \%$ \\
\hline 48 & Capital Expenditure & 39.8 & $56 \%$ & 42.0 & $40 \%$ & 46.1 & $29 \%$ & 63.7 & $21 \%$ & 66.4 & $20 \%$ & 100.2 & $24 \%$ & 100.2 & $24 \%$ \\
\hline 49 & Instalment/Loan Payment & 0.0 & $0 \%$ & 0.0 & $0 \%$ & 0.0 & $0 \%$ & 0.0 & $0 \%$ & 0.1 & $0 \%$ & 0.2 & $0 \%$ & 0.2 & $0 \%$ \\
\hline & Total & 70.6 & $\mathbf{1 0 0 \%}$ & 104.2 & $\mathbf{1 0 0 \%}$ & 160.0 & $\mathbf{1 0 0 \%}$ & 300.6 & $\mathbf{1 0 0 \%}$ & 339.9 & $\mathbf{1 0 0 \%}$ & 423.4 & $\mathbf{1 0 0 \%}$ & 423.4 & $\mathbf{1 0 0 \%}$ \\
\hline
\end{tabular}

Source: OSCE reports for 2005- 2007 combined with Author's Calculations from annual accounts 2008-2011 


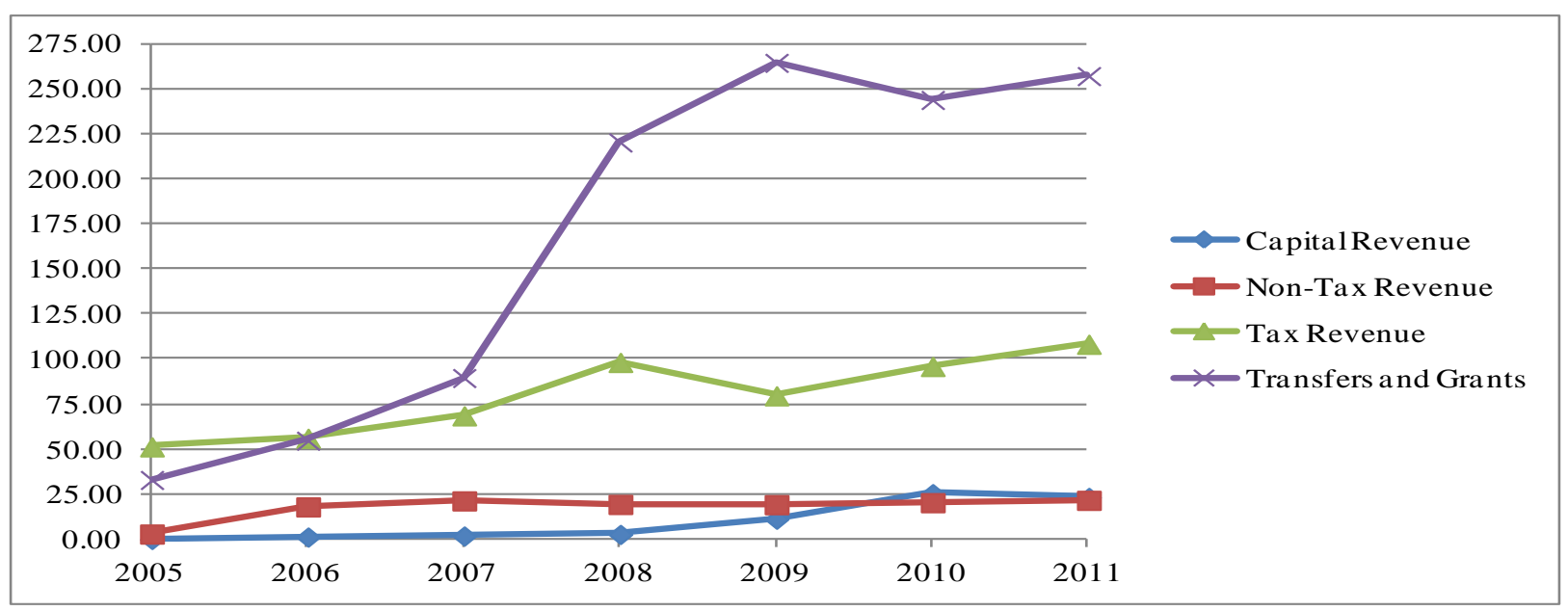

Chart 1. Local Government Revenues Compositions 2005-11

Source: Author's Calculations from LG annual accounts

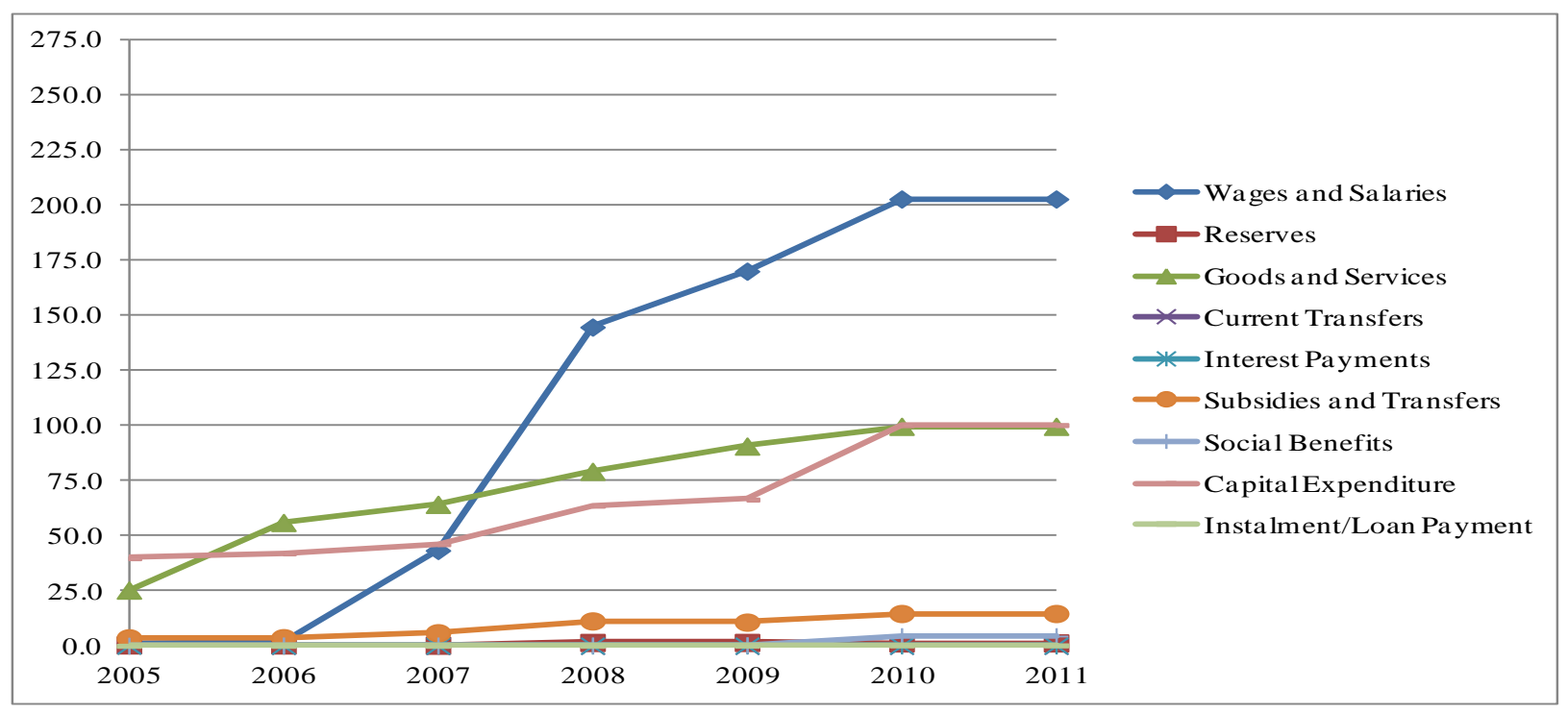

Chart 2. Local Government Expenditure Trend 2005-11

Source: Author's Calculations from LG annual accounts 


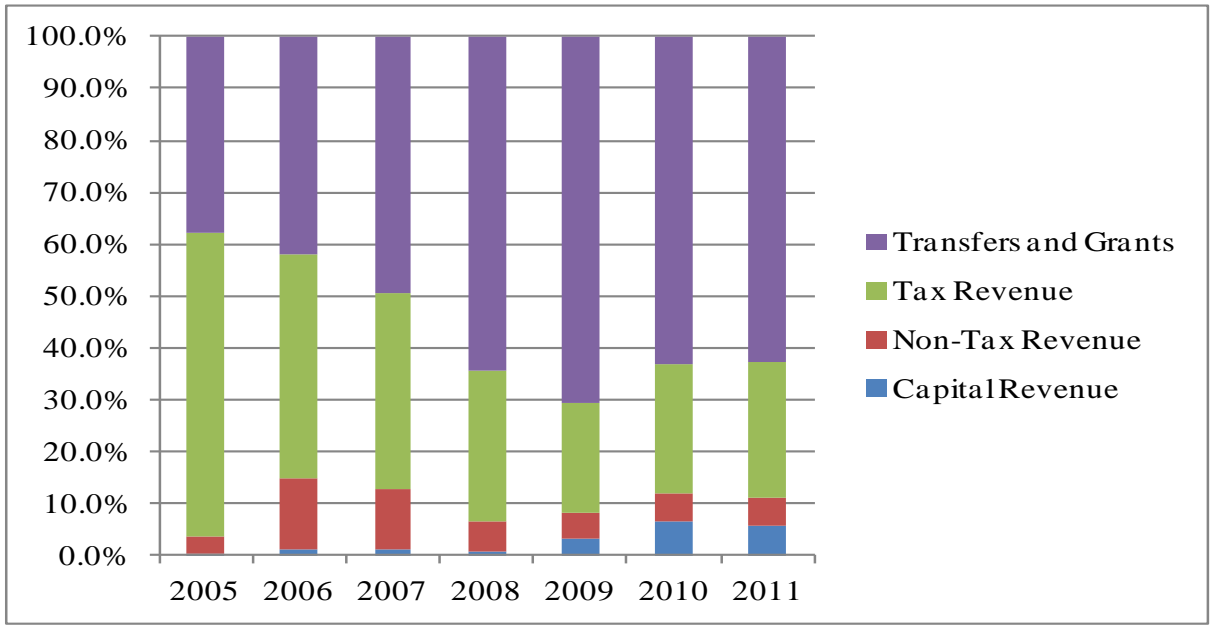

Chart 3. Local Government Revenues Composition

Source: Author's Calculations from LG annual accounts

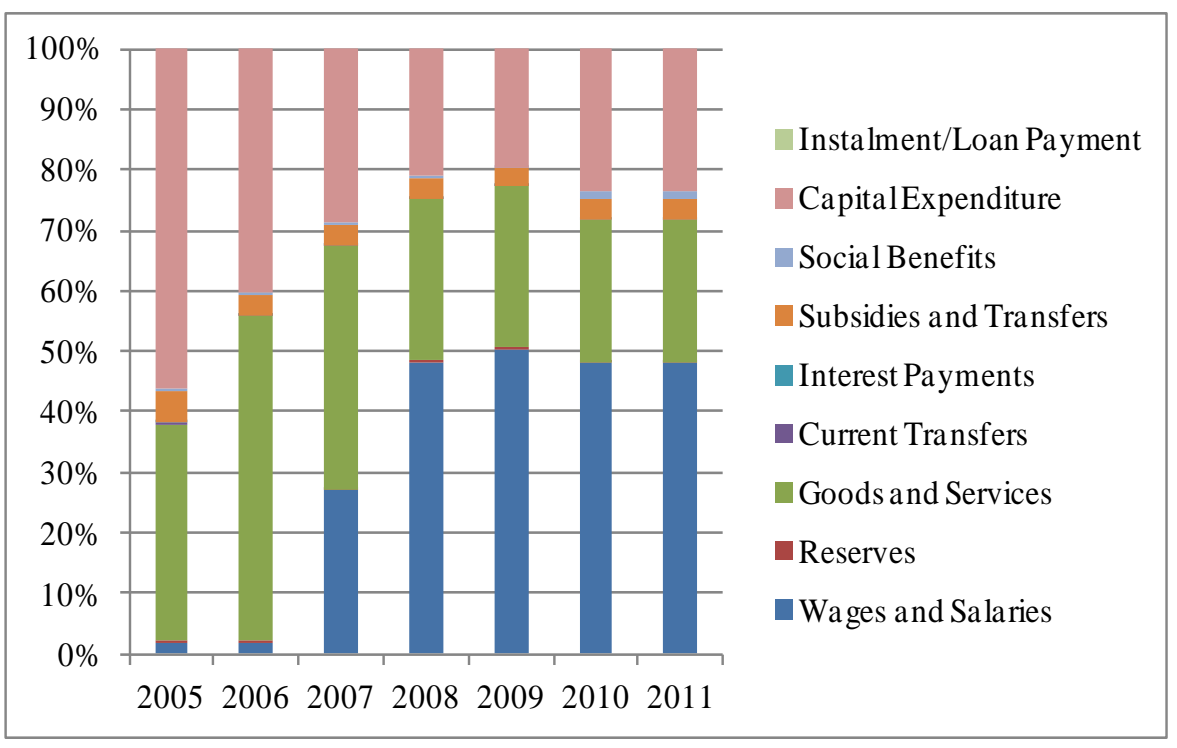

Chart 4 Local Government Expenditure Compositions

Source: Author's Calculations from LG annual accounts

Another aspect of the expenditure composition is according to the expenditure programs (specified so by the budget format) competencies of local government provided in Table 5 and Chart 5 in numbers and percentages for the period limited by the availability of the data 2008-2011. There has been a stable budget allocation and each expenditure programs have increased slightly. The total budget increase has been from $€ 300.7$ million in 2008 to $€ 423.4$ million in 2011. Among all expenditure programs, the largest budget share goes to the education expenditure (46.7\%; 49.7\%; $49.2 \%$ and $46.7 \%$ respectively) mainly covered by the transfers of central government. As expected the next largest expenditure program is that of the communal expenses ( $18 \%$ averagely), which is mainly financed by own revenues and it is fully administered by LGUs. Administration costs including Mayor's, Municipal Council's 


\section{Macrothink}

Business and Economic Research

ISSN 2162-4860

2016, Vol. 6, No. 1

and Municipal Administration, amount to $15 \%$ averagely. Development programs expenditure has a different trend compared to other expenditure programs, because it slumps from $€ 20.4$ million (6.8\%) in 2008 to $€ 0.01(0.003 \%)$ in 2009 and they remain so low until 2011.

Table 5. Local Expenditure According to Budgetary Programs

\begin{tabular}{|c|l|r|r|r|r|r|r|r|r|}
\hline $\begin{array}{c}\text { Program } \\
\text { Code }\end{array}$ & Expenditure Program & $\mathbf{2 0 0 8}$ & $\mathbf{2 0 0 8}$ & $\mathbf{2 0 0 9}$ & $\mathbf{2 0 0 9}$ & $\mathbf{2 0 1 0}$ & $\mathbf{2 0 1 0}$ & $\mathbf{2 0 1 1}$ & $\mathbf{2 0 1 1}$ \\
\hline A & Municipal Council & 8.16 & $2.7 \%$ & 8.61 & $2.5 \%$ & 9.35 & $2.5 \%$ & 9.07 & $2.1 \%$ \\
\hline D & Mayor & 4.58 & $1.5 \%$ & 4.64 & $1.4 \%$ & 4.49 & $1.2 \%$ & 4.54 & $1.1 \%$ \\
\hline E & Municipal Administration & 36.17 & $12.0 \%$ & 38.25 & $11.3 \%$ & 44.44 & $11.7 \%$ & 48.78 & $11.5 \%$ \\
\hline F & Urban Planning & 16.02 & $5.3 \%$ & 11.64 & $3.4 \%$ & 14.04 & $3.7 \%$ & 16.93 & $4.0 \%$ \\
\hline G & Assistance of LED & 2.36 & $0.8 \%$ & 2.54 & $0.7 \%$ & 3.57 & $0.9 \%$ & 7.57 & $1.8 \%$ \\
\hline J & Communnal Services & 54.96 & $18.3 \%$ & 58.51 & $17.2 \%$ & 66.01 & $17.3 \%$ & 79.65 & $18.8 \%$ \\
\hline K & Culture & 9.49 & $3.2 \%$ & 14.32 & $4.2 \%$ & 18.12 & $4.8 \%$ & 23.34 & $5.5 \%$ \\
\hline L & Sports \& Recreation & 1.96 & $0.7 \%$ & 1.40 & $0.4 \%$ & 1.45 & $0.4 \%$ & 2.51 & $0.6 \%$ \\
\hline M & Development Programs & 20.39 & $6.8 \%$ & 0.01 & $0.0 \%$ & 0.03 & $0.0 \%$ & 0.07 & $0.0 \%$ \\
\hline N & Education & 140.53 & $46.7 \%$ & 168.97 & $49.7 \%$ & 187.37 & $49.2 \%$ & 197.91 & $46.7 \%$ \\
\hline R & Protection of Environment & 0.50 & $0.2 \%$ & 0.43 & $0.1 \%$ & 1.29 & $0.3 \%$ & 0.83 & $0.2 \%$ \\
\hline T & Promotion of Health Care & 0.01 & $0.0 \%$ & 0.02 & $0.0 \%$ & 0.05 & $0.0 \%$ & 0.04 & $0.0 \%$ \\
\hline V & Social Care \& Child Protectid & 0.00 & $0.0 \%$ & 24.44 & $7.2 \%$ & 25.01 & $6.6 \%$ & 25.75 & $6.1 \%$ \\
\hline W & Fire Protection & 5.51 & $1.8 \%$ & 6.14 & $1.8 \%$ & 5.90 & $1.5 \%$ & 6.39 & $1.5 \%$ \\
\hline & Total Expenditure & $\mathbf{3 0 0 . 6 5}$ & $\mathbf{1 0 0 . 0 \%}$ & $\mathbf{3 3 9 . 9 1}$ & $\mathbf{1 0 0 . 0 \%}$ & $\mathbf{3 8 1 . 1 3}$ & $\mathbf{1 0 0 . 0 \%}$ & $\mathbf{4 2 3 . 4 0}$ & $\mathbf{1 0 0 . 0 \%}$ \\
\hline
\end{tabular}

Source: Author's Calculations from LG annual accounts

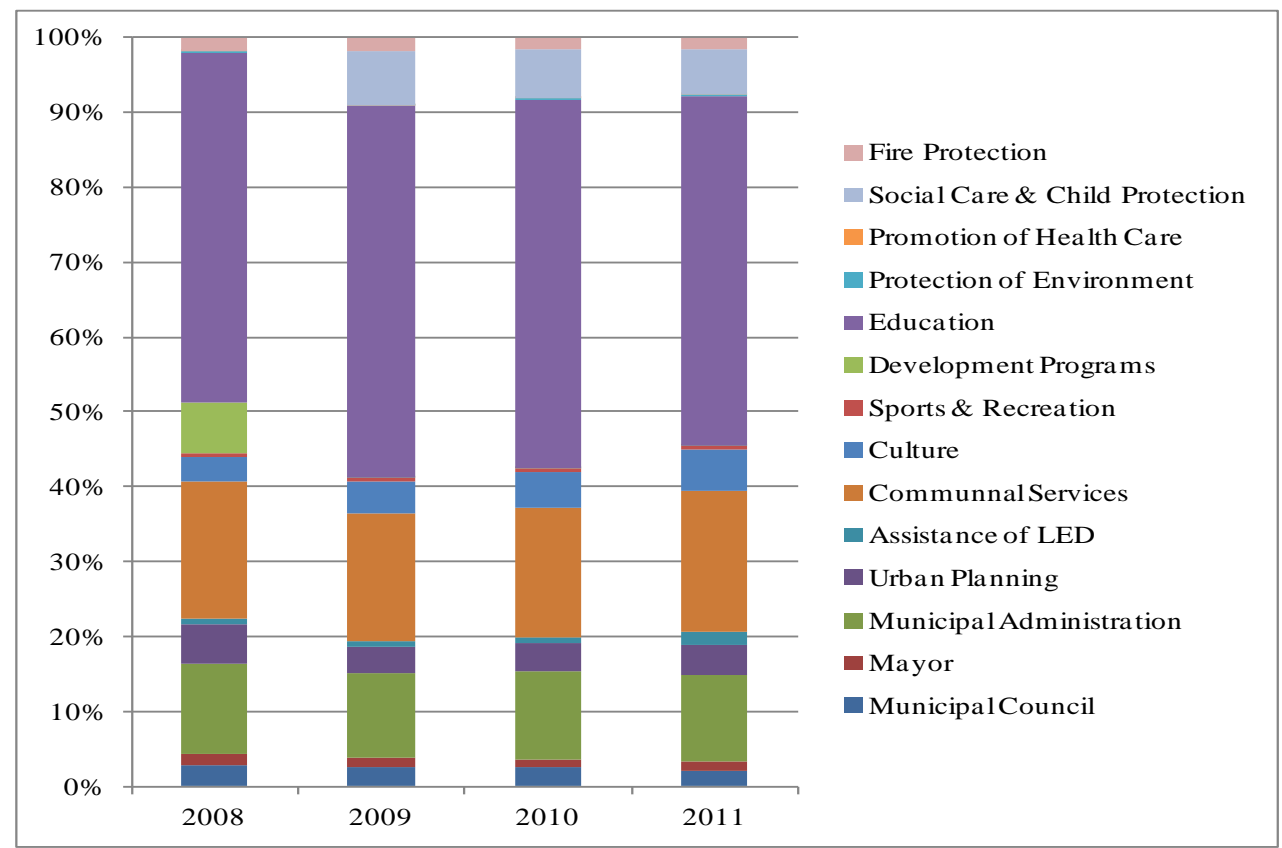

Chart 5. Local Expenditure According to Budgetary Programs

Source: Author's Calculations from LG annual accounts 


\section{Discussions: Current Situation of the Reform and Local Government}

Taking in considerations developments of the country since its independence, one may argue that the country has made significant progress towards reforming the local government, especially in the early years of its independence by introducing the necessary changes of the law. Later these laws were associated with decentralization programs to make the delegation of competencies smoother. However, the local government remains with the challenge of increased financial or fiscal decentralisation, especially when compared with EU member countries including those that are geographically close to Macedonia. Additionally, municipalities are facing still a number of challenges in terms of the necessary management and human resources that could contribute to more efficient and effective delivery of local government services.

One thing that could have been done different for decentralisation to be more effective is the consideration of the past decentralisation experience (during 1974-1991) of the country when it was part of Yugoslavia. Decentralisation programs should have incorporated the experience of the extended self-administering system and extremely developed neighbourhood system, where the direct involvement of citizens was a reality (Karkatsoulis, 2010). This system was characterised with high level competencies of even national defence and economic regulation. Financially speaking, LGUs had almost complete autonomy. Management like, LGUs were responsible for assigning the local officials, while political like, the local officials were elected by the voters. This extent of delegated powers often characterised Yugoslavia's local government "experiment" as unique worldwide.

Another issue of even changing the nature of the reform and local government itself is the conflict of 2001 among the two major ethnic groups, Macedonians and Albanians. It had its consequences in the continuation of the public administration reform, in addition to the consequences in economy and democratic institutions. As such, the country being exacerbated in its institutional weaknesses signed the OFA, which was supposed to accelerate further the decentralised power to the local governments of all ethnic groups and minorities parallel to the need of stabilising the institutions at country level. Currently, public attitude of major surveyed population (42\%) of Macedonian ethnic group perceives decentralisation as a possible mean to federalisation of the country (SEEDS Network 2002 cited by Karkatsoulis, 2010).

Another impediment to the reform on local government is considered the lack of necessary vision and strategy encompassing the most essential socioeconomic concerns of the society such as high level of unemployment, corruption, poverty reduction and ethnic conflicts aversion, (Karkatsoulis, 2010, p. 11). However, the Inter-Ministerial Decentralization Working Group and the Coordinating Body of State Secretaries were responsible of coordinating the decentralisation programs with other social and administrative reforms. Besides this inter-sectorial coordination and inclusion of the socioeconomic problems of the country, the decentralisation programs would have been more effective if they were communicated effectively to all of the local government stakeholders including citizens and NGOs as means of channelling citizens' voice. Therefore, the reforms would have produced more sustainable solutions and improve the citizen's welfare, if the citizen's attitude towards their problems was 
taken in consideration.

Overlapping leadership associated with confusion and lack of efficiency in local government operations is another obstacle to a successful decentralisation process. The model of Deputy Prime Minister and Minister of Local Self-government applied in transition countries and Macedonia, has been proven to lead to confusion of power, structure duplications, and even deadlock situations (Karkatsoulis, 2010, p. 12). Additionally, the lack of political will is common in the case of local government reforms all spheres of the society.

Finally, though there have been plenty of projects and money injection from the donors, often the approach of the donors has been far from facilitating. Their approach could have been more effective, if it incorporated the current situation and the nature of the problems of the local government of Macedonia.

Comparing the best practices of an affective budgeting to the current practices of budgeting in Macedonia, one can conclude that the country has made a progress in moving towards a modern system of local financial management. This progress is attached to the increased respect of the budget calendar and other associated activities of the budget process. In this line, there has been an improvement of the financial reporting in the depth of the cash statement itself, but not in preparing and reporting regularly other forms of financial reports that would show assets' current status, LGU arrears and so on. There is a lot more to be done in terms of developing performance-based budgeting, where LGUs would set their goals and priorities and then they would use effective financial planning, implementation and assessment mechanisms to channel their finances and resources towards the achievement of these goals. In this venture, there would be more decentralised approach of LGUs in finding some private sector management and economic tools for more efficient and effective local service provision.

\section{Conclusion and Recommendations}

Macedonia, after its independence was challenged to shift its economy towards an open-market economy. This required creating such public administration that would adjust to the above country's shift. Within this challenge, the country was pushed to accelerate PAR reforms at central as well as local level in a time where NPM tools were being applied worldwide and in Europe. Additionally, the domestic turmoil of 2001 and OFA agreement accelerated the PAR reform.

The need and attempt for PAR strategy started soon after independence, where the first PAR strategy was introduced in May 1999 considered to be as the key document on which the whole PAR reform was implemented and it served as a blueprint for many other legal documents adopted later. Currently, PAR remains a priority and it is seen as interrelated process with EU integration. The PAR 2010-2015 strategy is being implemented but with a selective approach different from the radical PAR strategy of 1999. Some of the expected outcomes of the PAR reform includes: improved quality of administrative services by offering rational and IT based solutions; improved public services by strengthening HRM; increased efficiency and effectiveness of public finance systems through improving 
budgetary process, financial control, development of program-based budgeting; and improved transparency by better public information access. However, there are still remaining challenges including local government in the form of financial controls and audit, continuing decentralization process, transparency, politicized PA that question the local government performance and efficiency.

Decentralization is an ongoing process of reforming the local government. There have been two important aspects of decentralization progress in the country. The first aspect has to do with the necessary legal reforms taken that prepare the local government to accept more delegated responsibilities guided mainly by the pillars of the European Charter of Self-Government. The legal milestone started with the adoption of Law on Local Self-Government (January 2002) and other related law that regulated the local government territory and delegated responsibilities or municipal services. More importantly, the Law on Local Self-Government Finances defined and regulated the revenue generation and fiscal management of LGUs.

The legal consolidation gave room to commencing the decentralization process in 1 July 2005 in form of administrative and financial decentralization or transfers. The second complementary aspect has been in translating the legal reform into five specific operational programs supporting decentralization, which were supposed to elaborate the implementation of reforms towards higher local autonomy. The decentralization process was a three phased approach customized to the specific nature of an LGU and its development level. All of the municipalities have moved to the last phase of decentralization. However, this does not necessary guarantee the decentralization success. There are critics that decentralization was politically-driven. Overlapping leadership and lack of efficiency in local government operations are perceived as obstacles to the decentralization. Very interesting point to make is how Macedonia did not make use of its past local government past success in Yugoslavia's time.

Pertaining to the financial and budget management, Macedonia is still far from the decentralization level of EU countries. Additionally, the very fact that data are not accessible even to the decision makers themselves show that management of tax payers money lacks transparency and hence accountability. Open budgetary decisions and inclusion of all stakeholders in the process would legitimize the LGUs financial management outcomes. Most importantly, better financial management would increase the pressure from LGUs to increased fiscal decentralization and therefore increase the financial capacity of LGUs to offer better public services to its citizens. The leadership should make sure not to interfere into the management of LGUs and allow citizens involvement not only in electing their local officials but also to collaborate with such officials so that at the end of the day, they receive qualitative municipal services at rates that are economically sound.

\section{References}

Analytica. (2007). Evaluation of Public Administration Reforms in Macedonia. Skopje: Analytica. 


\section{Macrothink}

Business and Economic Research ISSN 2162-4860 2016, Vol. 6, No. 1

Azizi, A. (2011). The Analysis of Public Administration Reforms in Macedonia and the Evaluation of the Performance of Public Administration by the European Commission. The 6th Edition of the International Conference: European Integration Realities and Perspectives, (pp. 884-888).

Clark, C. S. (2013). Reinventing Government -- Two Decades Later. Government Executive. Retrieved 2014, from http://www.govexec.com/management/2013/04/what-reinvention-wrought/62836/

HD-IPS, C. (2010). Public Administration Reform Strategy 2010-2015, Republic of Macedonia. Skopje: Strengthening the Capacity of the General Secretariat - Sector for Policy Analysis and Coordination - Unit for Public Administration Reform and Unit for NGO Cooperation.

Karkatsoulis, P. (2010). Local Self-government Reforms as an ambivialent means for peace and social inclusion: The Case of Former Yugoslav Republic of Macedonia. Athens: Paper to be presented at the Scientific event organised by the EPLO "Public Administration in the Balkans - from Weberian bureaucracy to New Public Management.

Markic, L. (n.d.). National Case-Study: Public Administration in the Republic of Macedonia. Skopje: Euro-Balkan Institute, Center for Public Administration and Public Policy. Retrieved from http://unpan1.un.org/intradoc/groups/public/documents/un/unpan031590.pdf

MOF. (2009). First Strategy of the Republic of Macedonia, 2010-12. Skopje: Ministry of Finance, Republic of Macedonia.

Nikolov, M. (2006). The Future of Local Government Finance: Case Studies from Romania, Bulgaria and Macedonia. Skopje: Center for Economic Analysis.

Oates, W. (1972). Fiscal Federalism. New York: Harcourt Brace Jovanovich.

O'Flynn, J. (2007). From New Public Management to Public Value:Paradigmatic Change and Managerial Implications. The Australian Journal of Public Administration, 66(3), 353-366. http://dx.doi.org/10.1111/j.1467-8500.2007.00545.x

Osborne, D. T. (1993). Reinventing Government. Leadership Abstracts; v6 n1.

Osborne, D., \& Plastrik, P. (1997). Banishing Bureaucracy: The Five Strategies for Reinventing Government. Jossey Bass, A Wiley Company.

Osborne, D., \& Plastrik, P. (2000). The Reinventor's Fieldbook: Tools for Transforming Your Government. San Francisco: Jossey-Bass, A Wiley Company.

OSCE. (2011). Decentralization Assessment Report 2006-2011. Skopje: OSCE Mission to Skopje.

Rhodes, R. A. (1996). The New Governance: Governing without Government. Political Studies, XLIV, 652-667. http://dx.doi.org/10.1111/j.1467-9248.1996.tb01747.x

Shah, A. (Ed.). (2006). Public Sector Governance and Accountability Series: Local 


\section{Macrothink}

Business and Economic Research

ISSN 2162-4860 2016, Vol. 6, No. 1

Governance in Developing Countries. Washington, D. C.: The World Bank. http://dx.doi.org/10.1596/978-0-8213-6565-6

Wollman, H. (2012). Local Government Reforms in (Seven) European Countries: Between Convergent and Divergent, Conflicting and Complementary Developments. Local Government Studies, 38(1), 41-70. http://dx.doi.org/10.1080/03003930.2011.638710

\section{Copyright Disclaimer}

Copyright for this article is retained by the author(s), with first publication rights granted to the journal.

This is an open-access article distributed under the terms and conditions of the Creative Commons Attribution license (http://creativecommons.org/licenses/by/3.0/). 